\title{
Positive effect of organic zinc supplementation on the persistence of anti-rabies neutralizing antibodies in healthy sheep
}

\section{Efeito positivo da suplementação de zinco orgânico na persistência de anticorpos neutralizantes anti-rábicos em ovinos saudáveis}

\author{
Luiz Fernando Coelho Cunha Filho ${ }^{1 *}$; Priscilla Gomes Carneiro ${ }^{2}$; Flavio Antonio \\ Barca Junior ${ }^{3}$; Agostinho Ludovico ${ }^{3}$; Fabíola Cristine de Almeida Rêgo Grecco ${ }^{3}$; \\ Maria Carolina Ricciardi Sbizera²; Marcela Lucas Lima²; José Victor Pronievicz \\ Barreto $^{4}$; Daniela Pinheiro Rinaldi ${ }^{7}$; Neuza Maria Frazatti Gallina ${ }^{5}$
}

\begin{abstract}
The main prophylactic tool to control rabies in herbivores is the systematic vaccination of susceptible animals. This study aimed to evaluate the positive effect of organic zinc ( $\mathrm{Zn}$ ) supplementation on the persistence of anti-rabies neutralizing antibodies in healthy sheep. A total of 36 Texel ewes were selected and randomly divided into 2 groups of 18 animals each. The treated group (TG) received organic Zn supplementation for 90 days, and after this period, 2 doses of rabies vaccine with a 30-day interval. The control group (CG) received the vaccine doses only and was not supplemented with organic $\mathrm{Zn}$. Blood samples were collected before the first vaccination and 30,60, and 90 days after vaccination, to determine the anti-rabies neutralizing antibody titer using the Rapid Fluorescent Focus Inhibition Test (RFFIT). The average values of anti-rabies serum-neutralizing antibodies 30 days after the first dose were $1.33 \pm 0.62 \mathrm{IU} \mathrm{mL}^{-1}$ for the $\mathrm{CG}$ and $1.57 \pm 0.80 \mathrm{IU} \mathrm{mL}^{-1}$ for the TG; 60 days after the second dose the average values were $7.60 \pm 7.08 \mathrm{IU} \mathrm{mL}^{-1}$ and $12.97 \pm 9.46 \mathrm{IU} \mathrm{mL}^{-1}$ for the $\mathrm{CG}$ and TG, respectively, with a significant difference between groups. The TG presented $100 \%$ vaccine coverage of the primary vaccination, whereas the CG presented $89.47 \%$ coverage. Oral supplementation with $75 \mathrm{mg}$ organic $\mathrm{Zn}$ significantly increased the persistence of anti-rabies antibody titers in sheep, and it improved the vaccine coverage of the primary vaccination.
\end{abstract}

Key words: Immunity curve. Mineral mixture. Rabies vaccine. Sheep. Zinc supplementation.

\section{Resumo}

A principal ferramenta profilática para o controle da raiva em herbívoro é a vacinação sistemática de animais susceptíveis. A presente pesquisa teve como objetivo avaliar o efeito positivo da suplementação de zinco orgânico na persistência de anticorpos neutralizantes anti-rábicos em ovinos saudáveis. Foram selecionadas 36 ovelhas Texel, aleatoriamente divididos em dois grupos com 18 animais cada. O grupo tratado (GT) recebeu suplementação com zinco orgânico durante 90 dias, e, após este período, foram administradas 2 doses de vacina anti-rábica com intervalo entre elas de 30 dias. O grupo controle (GC) recebeu apenas as doses da vacina, e não foi suplementado com zinco. Amostras de sangue foram

${ }_{1}^{1}$ Prof., Universidade Norte do Paraná, UNOPAR, Arapongas, PR, Brasil. E-mail: vtluiz.cunha@gmail.com

2 Pesquisadores, Mestrado em Saúde e Produção de Ruminantes, UNOPAR, Arapongas, PR, Brasil. E-mail: pirt1987@hotmail. com; carolsbizera@hotmail.com; marcelaveterinaria01@gmail.com

3 Profs., UNOPAR, Arapongas, PR, Brasil. E-mail: flavio.barca@unopar.br; agostinho.ludovico@kroton.com.br; fabiolaregogrecco@gmail.com

${ }^{4}$ Discente, UNOPAR, Arapongas, PR, Brasil. E-mail: jose.proni@hotmail.com

${ }_{5}$ Pesquisadores, Instituto Biológico de São Paulo, IBU, São Paulo, SP, Brasil. E-mail: rinaldi@gmail.com; galina@gmail.com

*Author for correspondence 
colhidas antes da primeira dose da vacina, e 30, 60 e 90 dias depois da vacinação, a fim de determinar o título de anticorpos neutralizantes anti-rábicos utilizando o teste rápido de inibição do foco fluorescente (RFFIT). As medias dos anticorpos anti-rábicos do soro, 30 dias após a primeira dose foi de 1,33 \pm $0,62 \mathrm{IU} \mathrm{mL}^{-1}$ para o grupo controle, e 1,57 $\pm 0,80 \mathrm{IU} \mathrm{mL}^{-1}$ para o grupo tratado. 60 dias após a segunda dose, as medias foram de 7,60 \pm 7,08 $\mathrm{IU} \mathrm{mL}^{-1}$ e 12,97 $\pm 9,46 \mathrm{UI} \mathrm{ml}^{-1}$ no GC e GT, respectivamente, com significância entre os grupos. O GT apresentou $100 \%$ de cobertura vacinal na primeira dose, enquanto o GC apresentou 89,47\%. A suplementação oral com $75 \mathrm{mg}$ de zinco orgânico aumentou significantemente a persistência de títulos de anticorpos anti-rábicos em ovinos, e melhorou a cobertura vacinal na primeira dose.

Palavras-chave: Curva de imunidade. Mistura mineral. Ovelhas. Suplementação com zinco. Vacina anti-rábica.

\section{Introduction}

There is scarcity of information describing the functional competency of the immune system and how management-related factors (i.e., nutrition, environmental conditions) influence the immune responsiveness and, ultimately, infectious disease resistance (NONNECKE et al., 2009). Many authors have studied how nutraceuticals interface with the immune response, with the clear objective of improving the protection of both animals and humans against various types of infections (BUN et al., 2011; GRUBER et al., 2013; NAGALAKSHMI et al., 2015). In studies of strategies to increase the defense mechanisms of the body, we highlighted the effects of nutrition on the immune response, and among the most studied nutrients were minerals and vitamins (SANTOS; FONSECA, 2006). Trace minerals are required for immune system integrity, vitamin synthesis, enzyme formation, and hormone structure (RABIEE et al., 2010).

Zinc $(\mathrm{Zn})$ is an essential mineral for animals, since it is present in several metallic enzymes, and it has paramount importance in the integrity of the immune system by increasing resistance to infectious diseases (CARVALHO et al., 2003). The immune system is particularly dependent on $\mathrm{Zn}$ (FRAKER; KING, 2004), and Zn deficiency has been implicated in immune function declination with age (HAASE et al., 2006).

$\mathrm{Zn}$ exerts a direct effect on the production, maturation, and function of leukocytes (MOCCHEGIANIetal.,2000).LowZnconcentration results in extensive damage to $\mathrm{T}$ lymphocytes, and modifies the synthesis of lymphocytes, which can induce immunosuppression (BRUNETTO et al., 2007). Trace minerals have an essential role in the maintenance of immunocompetence of animals (TEIXEIRA et al., 2014). Zn supplementation may increase immunocompetence and decrease the incidence and severity of some infections (viral, microbial, and parasitic) in individuals or animals with diagnosed or suspected $\mathrm{Zn}$ deficiency (FAILLA, 2003).

In Brazil, rabies is considered an endemic disease, with a very heterogeneous distribution. Due to its continental characteristics and its diversity of fauna, it is difficult to eradicate (LIMA et al., 2017). Annually, there are more than 1000 reports of rabies in livestock animals, particularly bovine, including horses and sheep, which, due to the underreported calculated rate for Brazil, results in annual deficits of millions of dollars (BRAZIL, 2009).

This disease is regarded as one of the most important zoonosis as it can cause fatal encephalitis in all mammals. It is distributed worldwide, and there is currently no effective therapy (DAHER, 2005). The common vampire bat (Desmodus rotundus) is widely distributed in Latin America, and is the major source of rabies virus infection in herbivores (ARELLANO-SOTA, 1988). Rabies transmitted by vampire bats in livestock has been controlled by reducing the population of vampire bats and by mass vaccination of cattle (MAYEN, 2003; MASSAD et al., 2011). Booster doses are 
required for effective protection, as one dose of vaccine is insufficient to protect the animals against rabies (ALBAS et al., 2005).

Due to the importance of vaccination for antirabies prophylaxis, it has been necessary to find ways to increase the effectiveness of vaccination against rabies (FERREIRA et al., 2009). In Brazil, the effect of $\mathrm{Zn}$ supplementation on the anti-rabies humoral immune response in cattle has been investigated, but the results are still not satisfactory, presumably due to the short period of Zn supplementation (MARIA et al., 2009), assuming that a significant increase in serum $\mathrm{Zn}$ levels is observed with prolonged administration of the mineral (CUNHA FILHO et al., 2009).

This study aimed to evaluate the positive effect of organic $\mathrm{Zn}$ supplementation on the persistence of anti-rabies neutralizing antibodies in healthy sheep.

\section{Materials and Methods}

\section{Study location and experimental design}

The experiment was conducted at a farm located in the city of Londrina, Paraná, Brazil. Thirty-six randomly selected Texel ewes with an average age of 14.6 months and $41.0 \mathrm{~kg}$ live weight (LW) were included. The animals $(\mathrm{n}=36)$ were divided into 2 groups (18 animals/group): treated group (TG) and control group (CG).

The animals in both groups were vaccinated with the commercial anti-rabies vaccine (D90) and received a booster 30 days after the first vaccination (D120), in compliance the recommendations of the Ministry of Agriculture, Livestock, and Supply (BRASIL, 2009).

\section{Supplementation and sampling}

The TG was supplemented with a mineral mixture (Cativa Ovinos ${ }^{\circledR}$ ) with the addition of organic Zn (Bioplex Zn ${ }^{\circledR}$ - Alltech do Brasil), and was immunized with 2 doses of a commercial rabies attenuated vaccine (Alurabiffa ${ }^{\circledR} / \mathrm{Merial} / \mathrm{SC}$, lot 006/11, needle $25 \mathrm{~mm}$ ); the CG was supplemented with mineral mixture only, without the addition of organic $\mathrm{Zn}$, and vaccinated according to the above protocol. All animals were vaccinated on the 90th day of the experiment, when the accumulated micromineral was predicted to be exerting a higher effect on the TG.

Each group was maintained in separate 5-hectare pickets, which had similar topography and were primarily inhabited by Brachiaria brizantha grass without fertilization. The animals were rotated monthly during the 180 days of the experiment. The CG received $500 \mathrm{~g}$ mineral mixture (inorganic $\mathrm{Zn}$ ) daily at the feeder, and the TG, in addition to receiving $500 \mathrm{~g}$ mineral mixture, was orally supplemented with $0.5 \mathrm{~g}(75 \mathrm{mg})$ head day ${ }^{-1}$ organic Zn during the experimental 180-day period.

At the onset of the experiment, animals were identified, weighed, and dewormed with $1 \%$ Moxidectin; parasitic worms were monitored by the Famacha ${ }^{\circledR}$ method every 15 days. At the beginning (D0) and at the end (D180) of the experiment, samples were collected from the water and the pastures of each picket to determine $\mathrm{Zn}$ concentration through atomic absorption spectrophotometry (AAS) performed at LaborSolo Laboratories.

Blood samples were collected at the time of vaccination (D90) and 30 (D120), 60 (D150), and 90 (D180) days after receiving the first dose in order to determine the anti-rabies neutralizing antibody titer, by the serum-neutralizing technique in $\mathrm{BHK}_{21}$ cells based in the rapid fluorescent focus inhibition test (RFFIT); this methodology was validated at Instituto Butantan in São Paulo, Brazil (MOURA et al., 2008).

\section{Ethics Committee on the usage of animals}

The experiment was carried out in accordance with the guidelines of the Ethics Committee on the usage of animals in experiments and was approved 
by the scientific committee (CEA/UNOPAR Results

007/11).

The World Health Organization (WHO) and World Organization for Animal Health (OIE)

\section{Statistical analysis}

The statistical package Minitab 13.0 was used for analysis of data; quantitative data underwent a variance analysis (ANOVA) with a 5\% minimum significance level. Data regarding correlations was evaluated by using Pearson's coefficient. adopted as an indicator to evaluate the effectiveness of rabies vaccine and immune response titers in humans and animals equal to or above $0.5 \mathrm{IU}$ $\mathrm{mL}^{-1}$ (WHO, 1992). The values for anti-rabies neutralizing antibody titers 30 days (D120) after primary vaccination were higher than those of references in both groups, demonstrating a higher titer in the TG. However, no statistically significant difference was observed between the 2 groups (Table 1).

Table 1. Antibody titers (IU mL $\mathrm{mL}^{-1}$ ) in sheep serum of the CG and TG with 2 doses of rabies vaccine, on day 90 and on day 120 .

\begin{tabular}{ccccc}
\hline GROUPS & \multicolumn{4}{c}{ Neutralizing antibodies titers $\left(\mathbf{I U} \mathbf{~ m L}^{-1}\right)^{1}$} \\
\hline & $\mathrm{D} 90$ & $\mathrm{D} 120$ & $\mathrm{D} 150$ & $\mathrm{D} 180$ \\
Treated & $\leq 0.12 \pm 0^{\mathrm{aA}}$ & $1.57 \pm 0.80^{\mathrm{aA}}$ & $15.47 \pm 10.76^{\mathrm{bB}}$ & $12.97 \pm 9.46^{\mathrm{bB}}$ \\
Control & $\leq 0.12 \pm 0^{\mathrm{aA}}$ & $1.33 \pm 0.62^{\mathrm{aA}}$ & $13.67 \pm 9.55^{\mathrm{bB}}$ & $7.60 \pm 7.08^{\mathrm{cA}}$ \\
\hline
\end{tabular}

${ }^{a}$ Lower-case letters at the same column indicate no significant difference $(p<0.05)$.

${ }^{\mathrm{A}}$ Capital letters at the same row indicate no significant difference $(p<0.05)$.

${ }^{1}$ Days of experiment: D90 = before vaccination; D120 = 30 days after the first vaccine dose; D150 = 60 days after the first vaccine dose. $\mathrm{D} 180=90$ days after the first vaccine dose.

As shown in Table 1, 90 days after primary vaccination (D180), the TG showed a persistent anti-rabies neutralizing antibody titer of $12.97 \pm$ 9.46 IU mL $\mathrm{mL}^{-1}$, statistically similar to that observed 60 days after vaccination (D150). However, the CG showed an average of $7.60 \pm 7.08 \mathrm{IU} \mathrm{mL}^{-1}$, which was less than that observed 60 days (D150) after the primary vaccination, with the significant difference between groups $(p \leq 0.05)$ demonstrating lower persistence.

The results displayed in Table 2 demonstrate that 30 days (D120) after the first vaccination, all the animals from the treated group (100\%) attained a protective anti-rabies neutralizing antibody titer equal or greater than that recommended by the WHO and $\mathrm{OIE}(2010),\left(\geq 0.5 \mathrm{IU} \mathrm{mL}^{-1}\right)$.

Table 2. Percentage of sheep with protective anti-rabies neutralizing antibody titer $\left(\geq 0.5 \mathrm{IU} \mathrm{mL}^{-1}\right)$ after vaccination.

\begin{tabular}{ccccc}
\hline GROUPS & \multicolumn{4}{c}{ \% serum conversion $\left(\right.$ antibodies $\geq \mathbf{0 . 5}{\left.\mathbf{~ I U ~} \mathbf{~ m L}^{-1}\right)^{\mathbf{1}}}$} \\
\hline TG & $\mathrm{D} 90$ & $\mathrm{D} 120$ & $\mathrm{D} 150$ & $\mathrm{D} 180$ \\
CG & 0 & 100 & 100 & 100 \\
& 0 & 89.47 & 100 & 100 \\
\hline
\end{tabular}

${ }^{1}$ Days of experiment: D90 = before vaccination; D120 = 30 days after the first vaccine dose; D150 = 60 days after the first vaccine dose; $\mathrm{D} 180=90$ days after the first vaccine dose. 
The average amount of $\mathrm{Zn}$ obtained through pasture samples collected at day $0(31,23 \mathrm{ppm}$ $\left.\mathrm{kg} \mathrm{DM}^{-1}\right)$ and day $180\left(27,93 \mathrm{ppm} \mathrm{kg} \mathrm{DM}^{-1}\right)$ was

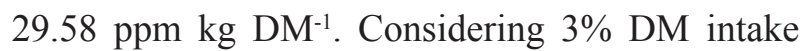
of LW and an absorption of only $60 \%$ of $\mathrm{Zn}$ found in the pasture (NRC, 2007), the total $\mathrm{Zn}$ individual consumption was $21.83 \mathrm{ppm}$ per day in the basal diet, which is less than the recommended level of $27 \mathrm{ppm}$ per day, reinforcing the need for mineral supplementation with Zn (NRC, 2007).

The quantity of $\mathrm{Zn}$ in the mineral mixture was $5000 \mathrm{ppm} \mathrm{kg}^{-1}$. Considering that the consumption of the mineral mixture was $21.82 \mathrm{~g}$ head day $^{-1}$ in both groups, which is within the expected consumption of 10-28 $\mathrm{g}_{\text {head day }}{ }^{-1}$ (PUGH, 2005), the individual total consumption of $\mathrm{Zn}$ in the mineral mixture was 65.46 ppm per day.

The level of organic $\mathrm{Zn}$ provided to the treated group consisted of $75 \mathrm{mg}$ head day ${ }^{-1}$.

The final average daily $\mathrm{Zn}$ intake was $87.45 \mathrm{ppm}$ and $162.45 \mathrm{ppm}$, in the $\mathrm{CG}$ and $\mathrm{TG}$, respectively; both values were higher than that recommended by the National Research Council (NRC).

\section{Discussion}

The rabies vaccine was used as a model to ascertain the effect of organic $\mathrm{Zn}$ supplementation in the interface of nutrition and effectiveness of rabies vaccine by immune response titers and the persistence of anti-rabies neutralizing antibodies. This model is advantageous in healthy sheep that have never been in contact with the virus, as contact with virus in animals that have never been previously vaccinated will necessarily cause clinical manifestation (DAHER, 2005).

The results obtained at 30 and 60 days after primary vaccination (Table 1) and the high daily $\mathrm{Zn}$ consumption in $\mathrm{CG}$, i.e. $87.45 \mathrm{ppm}$ per day, 3-fold higher than the value recommended by the NRC, justify the failure of significance of neutralizing antibody titers on days D120 and D150 between groups.

The WHO indicates that booster doses obtain higher antibody levels. It has been warned (PASTORET et al., 1995) that the use of only 1 dose of vaccine is not sufficient to protect animals against rabies; therefore, there is a need for boosting doses for the persistence of those antibodies. However, the results for effectiveness of rabies vaccine (Table 2) of the TG at 30 days after the first vaccine dose indicated that all animals in the TG would be protected before the booster dose, considering that the efficacy of the rabies vaccine is reached when titers become equal to or above $0.5 \mathrm{IU} \mathrm{mL}^{-1}$ (WHO, 1992). Although the CG presented an antibody average of $1.33 \pm 0.6 \mathrm{UI} / \mathrm{mL}$ (Table 1), 10.53\% of sheep showed titers below the protective value recommended by the WHO (Table 2), indicating that they would not be effectively protected against the rabies virus, thus requiring a reinforcement dose. Thereafter, the reinforcement applied 30 days after primary vaccination potentiated the humoral immune response in both groups, significantly increasing antibody levels 60 days after the primary vaccination to $15.47 \mathrm{IU} \mathrm{mL}^{-1}$ in the TG and to 13.67 IU $\mathrm{mL}^{-1}$ in the CG (Table 1); thus, the CG became protected based on the WHO exigency. The TG presented better primary vaccine coverage compared to the CG, which reinforces the benefits of organic $\mathrm{Zn}$ supplementation for better immunization.

Extrapolating the data obtained in this study to predict the persistence of anti-rabies neutralizing antibodies for annual revaccination, and considering that the TG did not have a significant decrease in neutralizing antibodies 90 days after the primary vaccination and 30 days after the booster, maintaining the titers (Table 1), we suggest that the revaccination protocol should be modified accordingly to persistence. Therefore, more studies should be carried out to elucidate the role of organic $\mathrm{Zn}$ supplementation in nutrition and vaccine effectiveness. 
$\mathrm{Zn}$ plays an important role in the immune system, including the synthesis of DNA and RNA, and consequently the replication and proliferation of immune cells (SPEARS; WEISS, 2008). Zn exerts a direct effect on the production, maturation, and function of leukocytes (MOCCHEGIANI et al., 2000), and on the specific cellular response through its role in clonal expansion of lymphocytes (SHANKAR; PRASAD, 1998). Consequently, supplementation of $\mathrm{Zn}$ in the diet of livestock animals is required (TOKARNIA et al., 2000) (PEIXOTO et al., 2005).

There is a natural decrease in antibody titers with time; nevertheless, 90 days after primary vaccination the group supplemented with organic $\mathrm{Zn}$ showed a titer of anti-rabies neutralizing antibody that was statistically similar to that observed 60 days after vaccination (Table 1), showing the persistence of anti-rabies neutralizing antibodies. In contrast, the CG presented lesser antibody titer than that presented at 60 days after the primary vaccination. This significant difference between groups ( $p \leq$ $0.05)$ demonstrated a lower persistence of antirabies neutralizing antibodies in animals that were not supplemented with organic $\mathrm{Zn}$. These results indicate that supplementing sheep with organic $\mathrm{Zn}$ increases the persistence of anti-rabies neutralizing antibodies.

A study (MARIA et al., 2009) that used 4 supplemental organic Zn schemes, 0, 2000, 4200, and $6000 \mathrm{mg} \mathrm{Zn} \mathrm{kg}{ }^{-1}$, concluded that supplementation did not significantly interfere with anti-rabies antibody titers in cattle. These data corroborate the results of a second study (SPEARS, 2000), which also noted that $\mathrm{Zn}$ supplementation did not change the production of antibodies against Infectious Bovine Rhinotracheitis. However, the short period of supplementation limits these resultsMaria et al. (2009) supplemented only for 90 days, whereas a significance increase in serum $\mathrm{Zn}$ was observed by Cunha Filho et al. (2009) only after 90 days of supplementation with organic $\mathrm{Zn}$.
$\mathrm{Zn}$ exerts a direct effect on the production, maturation, and function of leukocytes (MOCCHEGIANI et al., 2000). Low Zn concentration results in extensive damage to $\mathrm{T}$ lymphocytes and modifies the synthesis of lymphocytes, which can induce immunosuppression (BRUNETTO et al., 2007). Trace minerals have an essential role in maintaining the immunocompetence of animals (TEIXEIRA et al., 2014).

There are several reports that organic trace minerals (OTMs) are biologically more available than inorganic forms and can improve the health and productivity of ruminants (YOST et al., 2002); thus, there has been considerable interest in the use of OTMs in ruminant diets (RABIEE et al., 2010). Nemec et al. (2012) found that supplementation of $\mathrm{Zn}, \mathrm{Mn}$, and $\mathrm{Cu}$ as chelated sources may enhance the immune response of early lactating dairy cows compared to immune response in cows supplemented with inorganic sources.

Therefore, absorbable trace minerals may be supplied at a lower amount using OTMs rather than inorganic trace minerals. Alternatively, feeding similar levels of organic supplements in place of inorganic supplements may provide increased bioavailable trace minerals to support biological processes (NEMEC et al., 2012).

The result of higher vaccine coverage in the TG may be explained by the increased supply of $\mathrm{Zn}$ and its bioavailability, as $\mathrm{Zn}$ derived from organic sources has been shown to be 2-fold more bioavailable than the element from an inorganic source (CLOSE, 1998).

The quality of the immune response is highly dependenton theactivation-induced clonalexpansion of antigen-specific $\mathrm{T}$ cells and their differentiation into effector cells. Defects in activation, clonal expansion, and differentiation all have the potential to affect the immune response negatively (LEE et al., 2008). The antigenic stimulation of $B$ cells leads to subsequent hypermutation and selection processes, with the occurrence of a high response organized 
with a definite purpose, perhaps generated in germinal centers, forming plasmocytes and memory cells (LANZAVECCHIA; SALLUSTO, 2009). After each reinforcement, the repertoire of memory cells re-enters the hypermutation and selection cycle, generating an increase in plasmocytes, which peak (up to 100 -fold the basal level) at the $7^{\text {th }}$ day in peripheral blood. The increase in plasmocytes coincides with a rapid increase in serum antibodies, which reach a plateau at day 10 (LANZAVECCHIA; SALLUSTO, 2009).

\section{Conclusion}

Organic Zn supplementation positively interfered with the persistence of anti-rabies antibodies, which could allow for differentiated vaccination intervals for sheep supplemented with organic $\mathrm{Zn}$.

\section{Acknowledgements}

We thank Agda Luzia de Godoy Gimenes, MSc., for balancing the salt supplemented with organic Zn.

\section{References}

ALBAS, A.; PARDO, P. E.; BREMER NETO, H.; GALLINA, N. M. F.; MOURÃO FUCHES, R. M.; SARTORI, A. Vacinação anti-rábica em bovinos: comparação de cinco esquemas vacinais. Arquivos Instituto Biológico, São Paulo, v. 72, n. 2, p. 153-159, 2005.

ARELLANO-SOTA, C. Biology, ecology, and control of the vampire bat. Reviews of Infections Diseases, Oxford, v. 10, p. 615-619, 1988. Supplement 4.

BRASIL, Ministério da Agricultura, Pecuária e Abastecimento, Secretaria de Defesa Agropecuária. Ministério da Agricultura, Pecuária e Abastecimento. Programa Nacional de Controle de Raiva em Herbívoros. Brasília, DF, 2009. p. 55.

BRUNETTO, M. A.; GOMES, M. O. S.; JEREMIAS, J. T.; OLIVEIRA, L. D.; CARCIOFI A. C. Imunonutrição: o papel da dieta no restabelecimento das defesas naturais. Acta Scientiae Veterinariae, Porto Alegre, v. 35, n. 2, p. 230-232, 2007.
BUN, S. D.; GUO, Y. M.; GUO, F. C.; JI, F. J.; CAO, $\mathrm{H}$. Influence of organic zinc supplementation on the antioxidant status and immune responses of broilers challenged with Eimeria tenella 1. Poultry Science, Oxford, v. 90, n. 6, p. 1220-1226, 2011.

CARVALHO, F. A. N.; BARBOSA, F. A.; MCDOWELL, L. R. Nutrição de Bovinos a Pasto. Belo Horizonte: Papelform, 2003. 425 p.

CLOSE, H. W. Biodisponibilidade é a chave para uma suplementação mineral de sucesso. Feeding Times, Dublin, v. 3, n. 2, p. 37-39. 1998.

CUNHA FILHO, L. F. C.; CHIACCHIO, S. B.; GASTE, L.; GONÇALVES, R. C.; VIANNA, L. C. Concentração do zinco sérico em vacas leiteiras suplementadas com Saccharomyces cerevisiae, portadoras ou não de lesões podais. Semina: Ciências Agrárias, Londrina, v. 30, n. 2, p. 425-430, 2009.

DAHER, E. F. Renal involvement in human rabies: clinical manifestations and autopsy findings of nine cases from northeast of Brazil. Revista do Instituto de Medicina Tropical. São Paulo, v. 47, n. 6, p. 315-320, 2005.

FAILLA, M. L. Trace elements and host defence: recent advances and continuing challenges. Journal of Nutrition, Rockville, v. 133, n. 5, p. 1443-1447, 2003.

FERREIRA, L.A.; PARDO, P. E.; FRAZATTIGALLINA, N. M.; MOURÃO-FUCHES, R. M.; VENTINI, D. C.; KRONKA, S. N.; ARENAS, S. E.; REIS, L. S. L. S. Avaliação da vacinação antirrábica e da suplementação com probióticos na resposta imune humoral em bovinos. Semina: Ciências Agrárias, Londrina, v. 30, n. 3, p. 655660, jul./set. 2009.

FRAKER, P. J.; KING, L. E. K. Reprogramming of the immune system during zinc deficiency. Annual Review of Nutrition, Michigan, v. 24, n. 1, p. 277-298, 2004.

GRUBER, K.; RINK, L. The role of zinc in immunity and inflammation. In: CALDER, P. C.; YAQOOB, P. (Ed.). Diet, immunity and inflammation. Cambridge: Woodhead Publishing, 2013. p. 123-156.

HAASE, H.; MOCCHEGIANI, E.; RINK, L. Correlation between zinc status and immune function in the elderly. Biogerontology, Berlin, v. 7, n. 5-6, p. 421-428, 2006.

LANZAVECCHIA, A.; SALLUSTO, F. Human B cell memory. Current Opinion in Immunology, Amesterdã, v. 21, n. 3, p. 298-304, 2009.

LEE, W. W.; CUI, D.; CZESNIKIEWICZ-GUZIK, M.; VENCIO, R. Z. N.; SHMULEVICH, I.; ADEREM, A.; WEYAND, C. M.; GORONZY, J. J. Age-dependent signature of metallothionein expression in primary 
CD4 $\mathrm{T}$ cell responses is due to sustained zinc signaling. Rejuvenation Research, New York, v. 11, n. 6, p. 10011011, 2008.

LIMA, M. C. F.; MITTESTAINER J. C.; ROCHA, P. B.; CARVALHO E. R.; VEROTTI, B. P.; PELliCCIARI, P. R. Principais zoonoses em pequenos animais: breve revisão. Veterinária e Zootecnia, Botucatu, v. 24, n. 1, p 84-106, 2017.

MARIA, E. K.; PARDO, P. E.; FRAZATTI-GALLINA, N. M.; PAOLI, R. L.; MOURAO-FUCHES, R. M.; REIS, L.S. Efeito da suplementação com zinco na resposta immune humoral anti-rábica em bovinos. Archivos de Zootecnia, Córdoba, v. 58, p. 605-608; 2009. Supplement 1.

MASSAD, E.; COUTINHO, F. A.; BURATTINI, M. N., SALLUM, P. C.; LOPEZ, L. F. A mixed ectoparasitemicroparasite model for bat-transmitted rabies. Theoretical Population Biology, Stanford, v. 60, n. 4, p. 265-279, 2011.

MAYEN, F. Haematophagous bats in Brazil, their role in rabies transmission, impact on public health, livestock industry and alternatives to an indiscriminate reduction of bat population. Journal of Veterinary Medicine Series B: Infectious Diseases and Veterinary Public Health, Berlin, v. 50, n. 10, p. 469-472, 2003.

MOURA, W. C.; FRAZATTI-GALLINA, N. M.; FUCHES, R. M. M.; ROMIJN, P. C.; LEITE, J. P. G. Validation of a virus neutralization potency test in BHK21 cells for rabies immunoglobulins in a two-center study. Journal of Virological Methods, Hong Kong, v. 154 , n. $1-2$, p. 7-13, 2008.

MOCCHEGIANI, E.; MUZZIOLI, M.; GIACCONI, R. Zinc and immunoresistance to infection in aging: new biological tools. Trends in Pharmacological Sciences, New York, v. 21, n. 6, p. 205-208, 2000.

NAGALAKSHMI, D.; SRIDHAR, K.; PARASHURAMULU, S. Replacement of inorganic zinc with lower levels of organic zinc (zinc nicotinate) on performance, hematological and serum biochemical constituents, antioxidants status, and immune responses in rats. Veterinary World, Wankaner, v. 8, n. 9, p. 1156$1162,2015$.

NUTRIENT REQUIREMENTS OF SMALL RUMINANTS - NRC. Sheep, goats, cervids, and new world camelids. Zinc. $6^{\text {th }}$. ed. Washington, DC: National Academy Press, 2007. p. 266-267.
NEMEC, L. M.; RICHARDS, J. D.; ATWELL, C. A.; DIAZ, D. E.; ZANTON, G. I., GRESSLEY, T. F. Immune responses in lactating Holstein cows supplemented with $\mathrm{Cu}, \mathrm{Mn}$, and $\mathrm{Zn}$ as sulfates or methionine hydroxy analogue chelates. Journal of Dairy Science, Illinois, v. 95, n. 8, p. 4568-4577, 2012.

NONNECKE, B. J.; FOOTE, M. R.; MILLER, B. L.; FOWLER, M.; JOHNSON, T. E.; HORST, R. L. Effects of chronic environmental cold on growth, health, and select metabolic and immunologic responses of preruminant calves. Journal of Dairy Science, Illinois, v. 92, n. 12, p. 6134-6143, 2009.

OIE World Organization for Animal Health. Informe Anual de Salud Animal para la Notificación de la Ausencia o Presencia de Todas las Enfermedades, Paris. 2010. 1 p.

PASTORET, P. P.; THOMAS, I.; BROCHIER, B.; SCHWERS, A. Les problèmes associés à la vaccination antirabique des animaux domestiques. Annales de Médecine Vétérinaire, Liège, v. 129, n. 1, p. 339-349; 1995.

PEIXOTO, P. V.; MALAFAIA, P.; BARBOSA, J. D; TOKARNIA, C. H. Princípios sobre suplementação mineral e a sanidade de ruminantes. Pesquisa. Veterinária Brasileira, Rio de Janeiro, v. 25, n. 3, p. 195-200, 2005.

PUGH, D. G. Clínica de ovinos e caprinos. São Paulo: Roca, 2005. 31 p.

RABIEE, A. R.; LEAN, I. J.; STEVENSON, M. A.; SOCHA, M. T. Effects of feeding organic trace minerals on milk production and reproductive performance in lactating dairy cows: a meta-analysis. Journal of Dairy Science, Illinois, v. 93, n. 9, p. 4239-4251, 2010.

SANTOS, M. V.; FONSECA, L. F. L. Estratégias para controle de mastite e melhoria da qualidade do leite. Barueri: Manole, 2006. 314 p.

SHANKAR, A. H.; PRASAD, A. S. Zinc and immune function: the biological basis of altered resistance to infection. The American Journal of Clinical Nutrition, Rockville, v. 68, p. 447-463, 1998. Supplement 2.

SPEARS, J. W. Micronutrients and immune function in cattle. Proceedings of the Nutrition Society, Cambridge, v. 59, n. 4, p. 587-594, 2000.

SPEARS, J. W.; WEISS, W. P. Role of antioxidants and trace elements in health and immunity of transition dairy cows. Veterinary Journal, London, v. 176, n. 1, p. 70-76, 2008. 
TEIXEIRA, A. G. V.; LIMA, F. S.; BICALHO, M. L. S.; KUSSLER, A.; LIMA, S. F.; FELIPPE, M. J.; BICALHO, R. C. Effect of an injectable trace mineral supplement containing selenium, copper, zinc, and manganese on immunity, health, and growth of dairy calves. Journal of Dairy Science, Illinois, v. 97, n. 7, p. 4216-4226, 2014.

TOKARNIA, C. H.; DÖBEREINER, J.; PEIXOTO, P. V.; CANELLA, C. F. C. Deficiências minerais em animais de fazenda, principalmente bovinos. Pesquisa. Veterinária Brasileira, Rio de Janeiro, v. 20, n. 3, p. 127138, 2000.
WORLD HEALTH ORGANIZATION - WHO. Expert Committee on Rabies. Geneva, Switzerland. 1992. 51 p.

YOST, G. P.; ARTHINGTON, J. D.; MCDOWELL, L. R.; MARTIN, F. G. Effect of copper source and level on the rate and extent of copper repletion in Holstein heifers. Journal of Dairy Science, Illinois, v. 85, n. 12, p. 3297 3303, 2002. 
